Eastern Illinois University

The Keep

2012

Impact of Family Meal Time on College Students' Food Consumption and Select Lifestyle Choices

Rachael Jannusch

Follow this and additional works at: https://thekeep.eiu.edu/honors_theses

Part of the Dietetics and Clinical Nutrition Commons 
IMPACT OF FAMILY MEALTIME ON COLLEGE STUDENTS' FOOD CONSUMPTION AND SELECT LIFESTYLE CHOICES

(TITLE)

BY

RACHAEL JANNUSCH

\section{UNDERGRADUATE THESIS}

SUBMITTED IN PARTIAL FULFILLMENT OF THE REQUIREMENTS OF

UNDERGRADUATE DEPARTMENTAL HONORS

DEPARTMENT OF FAMILY AND CONSUMER SCIENCES, ALONG WITH

THE HONORS COLLEGE,

EASTERN ILLINOIS UNIVERSITY

CHARLESTON, ILLINOIS

\begin{tabular}{l}
2012 \\
\hline YEAR
\end{tabular}

I HEREBY RECOMMEND THIS UNDERGRADUATE THESIS BE ACCEPTED AS

FULFILLING THE THESIS REQUIREMENT FOR

UNDERGRADUATE DEPARTMENTAL HONORS

$\frac{5 / 4 / 2012}{\text { DATE }}$

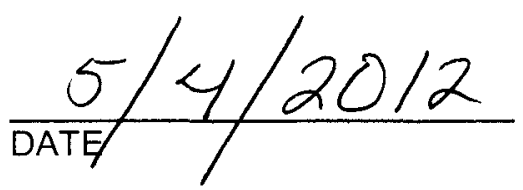

$\frac{5 / 1 / 2012}{\mathrm{DATE}}$
THFSIS ADVISOR

HONORS COORDINATOR'

DEPAKTMENII CHAIR 
Copyright 2012 Rachael Jannusch

All Rights Reserved 


\begin{abstract}
People participating in family mealtimes $\geq 6$ times per week while growing up are known to have a better quality diet, GPA, sleeping habits, and a normal BMI. It is hypothesized that college students with a history of family mealtimes continue to experience these benefits while in college. The purpose of this study is to investigate the impact of the history of family mealtime on diet quality, GPA, sleeping habits, and BMI in a college setting.

A convenience sample of students at a midwestern university $(n=100)$ were asked to complete a 17 question survey regarding frequency of family meals, food frequency, GPA, sleep, and BMI. GPA was evaluated on a five point scale (one $\leq$ $2 \cdot 0$, two $=2 \cdot 1-2 \cdot 5$, three $=2 \cdot 6-3 \cdot 0$, four $=3 \cdot 1-3 \cdot 5$, five $=3 \cdot 6-4.0)$. Data were analyzed using a one-tailed, two-sample unequal variance $t$-test in Microsoft Excel. SPSS was also used for statistical analysis. Study protocol was approved by the university IRB.
\end{abstract}

College participants growing up eating in a family dinner setting $\geq 6$ days a week had a non-significant $(p \geq 0.05)$ increase intake of fruits, grains, dairy, and hours of sleep compared to those $\leq 3$ times per week. There was a non-significant $(p \geq 0.05)$ decrease in daily convenience food consumption and normal BMI between the groups. Also, there was a significant $(p \leq 0.05)$ increase in GPA from 3.32 to 4.20 $(p=0.002)$ between the groups. These findings indicate that growing up eating in a family dinner setting $\geq 6$ days a week is associated with better GPA in college. 


\section{Acknowledgements}

I would like to thank the following people for their support throughout this research process:

Dr. Honselman, my thesis advisor, for all her help, expertise, commitment and patience to this project. Without your help, I would have been lost and overwhelmed. You have really kept me motivated during this entire process of twists and turns.

Dr. Painter and his graduate students, for helping me to develop my abstract.

My family and friends, for their support and motivation even on the late nights and early mornings. 
Chapter 1: Introduction

Chapter 2: Literature Review

Chapter 3: Methodology

Chapter 4: Results

Chapter 5: Discussion, Limitations, \& Conclusion

\section{Table of Contents}

Statement of Problem

Purpose of Study

Research Questions

Hypothesis

Definition of Terms

Family as an Institution

Family as a Model for

Healthy Lifestyle

Design of Study

Data Collection

Instrument

Procedure for Data

Collection

Data Analysis
1

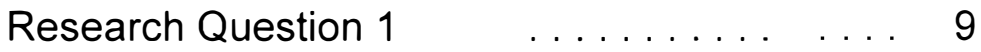

Research Question $2 \quad \ldots \ldots \ldots . . . . . .410$

Research Question $3 \quad \ldots \ldots \ldots \ldots . . . .10$

Research Question $4 \quad \ldots \ldots \ldots . . . .611$

Discussion

Research Question $1 \quad \ldots \quad 13$

Research Question $2 \quad \ldots \quad 13$

Research Question $3 \quad \ldots \quad 13$

Research Question $4 \quad \ldots . \quad 14$

Limitations $\quad \ldots \ldots \ldots \ldots . . . . .14$

Conclusion $\quad \ldots \ldots \ldots \ldots . . . . .15$

Recommendations for $\quad \ldots \ldots \ldots . . . .615$

Future Studies

\section{10
1}

1
1




\section{Chapter 1 \\ Introduction}

\section{Statement of Problem}

As our culture has evolved within the last fifty years, there has been an increase in obesity rates. Research has identified the following risk factors for obesity: overweight, physical inactivity and low fruit and vegetable intake (Wilson, Blakely, Foster, Hadorn, \& Vos, 2011). Studies have shown that familial dining has influences on lifestyle and dining choices of children (Birch \& Davidson, 2001, Kovivisto-Hursti, 1999, \& Roblin, 2007). It is imperative to look at past and current research in the field to gain an understanding of what is known about the impact of familial dining on outcomes such as diet quality, GPA, sleeping habits, and BMI in a college setting.

\section{Purpose of Study}

This study targets a specific age sector (college students) to explore this population's past eating habits and connection to current eating, exercising, and sleeping habits. This study is the first of its kind to the researcher's knowledge. When away at college, students experience a change from normal lifestyle at home. Many students are on their own for the first time. They may have to learn skills for needs that have previously been met through the family or develop new skills necessary for college living. The purpose of this study is to investigate the impact of the history of family mealtime on diet quality, GPA, sleeping habits, and BMI in a college setting. 


\section{Research Questions}

1. How frequently did students share a family dinner while growing up?

2. Do college students with a history of familial dinnertime continue to dine with others at college?

3. Does a higher frequency of familial dinnertime correlate with a higher quality diet in college?

4. Do college students with a higher frequency of familial dinners have other health benefits that can be assessed as part of a healthy lifestyle?

\section{Hypothesis}

It is hypothesized that college students with a history of family mealtimes will have a better diet quality, GPA, sleeping habits, and BMI while in college.

\section{Definition of Terms}

1. Familial dinner-An evening meal shared with family members.

2. Growing up-A section of participant's life from elementary through junior high school.

3. Diet quality-The frequency and amount of food groups consumed during college.

4. GPA-Grade Point Average in college

5. BMI-Body Mass Index is a measure of body fat in accordance with the height and weight of an individual (Calculate your body mass index, 2012). 


\section{Chapter 2 Literature Review}

This study seeks to find what the impact of familial dining and lifestyle behaviors in young adults is. The family is not only in charge of surrounding the developing child with appropriate choices for food, but it is also responsible for modeling behavior that the child will follow (Davison \& Birch, 2002). For example, if the parents provide a healthy environment for a child, the child is more likely to follow it.

One study suggests that while the family has a large influence over the child, often times the media, specifically television, can eclipse the role that the family is trying to portray (Taylor, Evers, \& McKenna, 2005). That study also notes that the nature of other foods available to children and parenting style will factor into the development of the lifestyle preferred by the child and future adolescent. Birch and Davidson (2001) have also noted that the family environment and parents are the major influences for children during the early and middle childhood stages. Children develop their own food preference, eating style, pattern of food intake, and activity preferences during this time. Children also pick up on parents' eating behaviors and food preferences. It is important that parents are setting good examples for them (Kovivisto-Hursti, 1999). Another study confirmed that parents have a major influence over nutrient intake in their children with the mother having the most influence (Oliveria et al., 1992). Nicklas et al. (2001) introduced the idea that caregivers have just as much influence over childhood development of healthy eating styles as parents do because of the amount of time that children spend with their caregiver. The nutrient intake and eating style of the parents will dictate what 
food is bought and therefore is in the environment of the child (Ventura \& Birch, 2008). It is also been found that children respond better to food role models that are eating the same foods (Addessi, 2005). Adolescents and young adults make food decisions on what becomes familiar to them which stems from their childhood (Rheingold, 1985; Birch et al., 1982; Birch et al., 1990).

There are numerous benefits that are results of having a familial dinner. Roblin (2007) states that family dinner is an important part of structure in a child's life that allows parents to be role models for healthy eating patterns. He found that it also provides opportunities to build good communication skills. Family dinners that are not centered on the television provide opportunities for children to express themselves, as well as controlling the amount of calories consumed due to mindless eating behaviors (Veugelers, Fitzgerald, \& Johnston, 2005). The presence of family and friends at a meal time extends the duration of the meal which can be beneficial or harmful (de Castro, 1994). By lengthening the meal, more food can be consumed which can lead to overeating and excess weight gain. However, it can be beneficial if more time is spent between bites, the consumer has a chance of realizing satiety before overconsumption (1994). Several studies have also found that families that ate together had a better food intake including consuming less soft drinks, saturated fat, fried food, trans fat and consuming more fruits, vegetables, fiber, and essential nutrients (Gilman et al., 2000; Neumark-Sztainer et al., 2003; Taveras et al., 2005; Utter et al., 2008; Woodruff et al., 2010). Fisher et al. (2004) found that mothers that consumed more milk had daughters that also consumed more milk than their peers. 
In order to see the benefits from eating together, Veugelers \& Fitzgerald (2005) found that a minimum of three meals per week were required. 


\section{Chapter 3 \\ Methodology}

\section{Design of Study}

This was a cross sectional study that looked at the impact of the history of family mealtime on diet quality, GPA, sleeping habits, and BMI in a college setting. The participants were part of a convenience sample at a midwestern university. The Institutional Review Board (IRB) approved the study.

\section{Sample}

The sample consisted of a convenient sample of 100 students. They were chosen from a population of 11,630 students at the midwestern university. Student volunteers in select classes were asked to fill out a survey. The principle investigator excluded classes that were taught in the Family and Consumer Sciences Department to avoid a potential bias. The participants were between the ages of 18 and 26 years old. The sample was $34 \%$ male and $66 \%$ female.

\section{Data Collection Instrument}

The instrument used for data collection was self-developed using food frequency questionnaires. For the purpose of analysis, participants were categorized into groups based on their history of familial meal frequency. The investigator wanted to know if familial meal time was a learned behavior that was carried by the individual to the college setting. The review of literature revealed that similar studies group meal frequency as follows: $0-3$ times per week $(n=19), 4-5$ times per week $(n=41)$, and 6-7 times per week $(n=40)$. This method of grouping frequencies was used for further comparison of other research questions. 
The instrument was reviewed by a registered dietitian for validity. The instrument was tested in a pilot study completed by ten students. These students reported difficulty in completing the food frequency questions. The investigator revised the questions based on food frequency questionnaires found in the literature.

\section{Procedure for Data Collection}

Professors were asked for permission to administer the survey to their students. Based on their willingness to participate in the study, participants were given an informed consent form prior to survey distribution. All participants remained anonymous throughout data collection. Participants did not provide their name at any point during the study. Professors did not disclose the name of the course or student information either. All surveys have been stored with the principle investigator. The data analysis was kept on the researcher's computer and flash drive under password protection.

\section{Data Analysis}

There were 100 participants that completed surveys. Only one participant did not provide a height and weight so the BMI could not be calculated, but all other data from that survey was used in the analysis. BMI was computed and categorized in accordance to the standards on the National Heart, Lung, and Blood Institute's website (Calculate your body mass index). The Dietary Guidelines for Americans and standard serving sizes were used to define a quality diet and the recommended level for exercise and hours of sleep (2010).

Data were analyzed using Microsoft Excel. A one-tailed, two-sample unequal variance t-test was used to find the significance between the $0-3$ meal history 
frequency group and the 6-7 meal history frequency group, the two extremes. The two extremes were used for comparison in order to have a better understanding if there is an impact of family mealtime on college students' food consumption and select lifestyle choices. 


\section{Chapter 4 \\ Results}

The purpose of the study was to investigate the impact of the history of family mealtime on diet quality, GPA, sleeping habits, and BMI in a college setting. It was hypothesized that college students with a history of family mealtimes will have a better diet quality, GPA, sleeping habits, and BMI while in college. The hypothesis was rejected because a higher frequency of familial dinner did not lead to a better quality diet, GPA, sleeping habits, and BMI while in college. There was however, a significant increase in GPA ( $p=0.002)$ for participants that had a familial dinner time 6-7 days per week compared to those that had familial dinner time $0-3$ days per week.

Research Question 1: How frequently did students share a family dinner while growing up?

In a group of 100 students, $19 \%$ had a familial dining history of $0-3$ nights per week, $41 \%$ had a history of $4-5$ nights per week, and $40 \%$ had a history of $6-7$ nights per week. For sake of analysis, comparison can be made between the two extremes. See Results in Table 1.

Table 1.

Percentage of participants $(n=100)$ according to familial dining frequency history

Familial Meal Frequency 0-3 meals per week 4-5 meals per week 6-7 meals per week History

Percentage of participants

$19 \%$

$41 \%$

$40 \%$ 
Research Question 2: Do college students with a history of familial dinnertime continue to dine with others at college?

Of the participants that had family dinner time 0-3 times per week $(n=19)$, $26 \%$ sought out others for dinner 6-7 times per week. Of the participants that had family dinner time 6-7 times per week $(n=40), 40 \%$ continued to eat with others 6-7 times per week. See Results in Table 2.

Table 2.

College Meal Frequency: Percentage of participants within the same familial history frequency group that seek out others during mealtime in college

\begin{tabular}{lccc}
$\begin{array}{c}\text { Meal Frequency in } \\
\text { College }\end{array}$ & $\begin{array}{c}\text { Family History 0-3 } \\
\text { times/ week }(n=19)\end{array}$ & $\begin{array}{c}\text { Family History 4-5 } \\
\text { times/ week }(n=41)\end{array}$ & $\begin{array}{c}\text { Family History 6-7 } \\
\text { times/week }(n=40)\end{array}$ \\
0-3 meals/week & $47 \%$ & $61 \%$ & $40 \%$ \\
4-5 meals/week & $26 \%$ & $15 \%$ & $25 \%$ \\
6-7 meals/week & $26 \%$ & $24 \%$ & $35 \%$ \\
Total & $100 \%$ & $100 \%$ & $100 \%$ \\
\hline
\end{tabular}

\section{Research Question 3: Does a higher frequency of familial dining correlate to a} higher quality diet in college?

There was a non-significant $(p \geq 0.05)$ increase in fruit $(5 \%)$, grains $(2 \%)$, and dairy (3\%) intake between the 0-3 familial meal frequency and 6-7 familial meal frequency groups. There was a non-significant $(p \geq 0.05)$ decrease in convenience food consumption $(6 \%)$ between these groups. Non-significant $(p \geq 0.05)$ decreases were found in vegetable $(1 \%)$, whole grains $(8 \%)$, and protein $(9 \%)$ intake between the two groups. See results in Table 3 . 


\begin{tabular}{|c|c|c|c|c|}
\hline \multicolumn{5}{|c|}{$\begin{array}{l}\text { Table } 3 . \\
\text { Percent of food frequency in college among same familial } \\
\text { history frequency group }\end{array}$} \\
\hline Measured Intake & $\begin{array}{l}\text { Standard for } \\
\text { Analysis }\end{array}$ & $\begin{array}{l}\text { 0-3 Familial Meal } \\
\text { Frequency }(n=19)\end{array}$ & $\begin{array}{l}\text { 6-7 Familial Meal } \\
\text { Frequency }(n=40)\end{array}$ & $\mathrm{p}$ Value \\
\hline Fruit & $2+/$ day & $5 \%$ & $10 \%$ & 0.39 \\
\hline Vegetables & $2+/$ day & $26 \%$ & $25 \%$ & 0.29 \\
\hline Grains & $5+/$ day & $11 \%$ & $13 \%$ & 0.49 \\
\hline Whole Grains & $\geq 1 / 2$ of grains & $58 \%$ & $50 \%$ & 0.31 \\
\hline Dairy & $2+/$ day & $32 \%$ & $35 \%$ & 0.35 \\
\hline $\begin{array}{l}\text { Protein } \\
\text { Convenience }\end{array}$ & $2+/$ day & $47 \%$ & $38 \%$ & 0.34 \\
\hline Food & 1-2/ week & $47 \%$ & $53 \%$ & 0.12 \\
\hline
\end{tabular}

\section{Research Question 4: Do college students with a higher frequency of familial dinners have other health benefits that can be assessed as part of a healthy lifestyle?}

When comparing the two groups, there was a non-significant $(p \geq 0.05)$ increase in exercising for at least 30 minutes a day outside of normal activities for 57 days per week (4\%), sleeping $7-9$ hours a night (20\%), and BMI (23\%) for the group with a history of 6-7 familial meal frequency. In the 0-3 familial meal frequency, $21 \%$ of participants had a GPA of $3.1-4.0$ compared to $75 \%$ of participants in the 6-7 familial meal frequency $(p=0.002)$. See results in Table 4 . 


\begin{tabular}{|c|c|c|c|c|}
\hline $\begin{array}{l}\text { Measured } \\
\text { Characteristic }\end{array}$ & $\begin{array}{l}\text { Standard for } \\
\text { Analysis }\end{array}$ & $\begin{array}{l}\text { 0-3 Familial Meal } \\
\text { Frequency }(n=19)\end{array}$ & $\begin{array}{l}\text { 6-7 Familial Meal } \\
\text { Frequency }(n=40)\end{array}$ & $\begin{array}{c}\mathrm{p} \\
\text { Value }\end{array}$ \\
\hline Exercise & $\begin{array}{l}5-7 \text { Days/Week of } \\
\geq 30 \text { Minutes }\end{array}$ & $21 \%$ & $25 \%$ & 0.14 \\
\hline $\begin{array}{l}\text { Hours } \\
\text { Sleep }\end{array}$ & 7-9 Hours/Night & $53 \%$ & $73 \%$ & 0.08 \\
\hline $\mathrm{BMI}$ & $18.5-24.9$ & $42 \%$ & $65 \%$ & 0.21 \\
\hline GPA & $3.1-4.0$ & $21 \%$ & $75 \%$ & 0.002 \\
\hline
\end{tabular}




\section{Chapter 5 \\ Discussion, Limitations, \& Conclusion}

\section{Discussion}

Research Question 1: How frequently did students share a family dinner while growing up?

The small sample size for the familial dining frequency in the 0-3 meals a week could potentially have an adverse effect in the results. The participants were evenly distributed between the 4-5 meal frequency group and the 6-7 meal frequency group. It was decided to compare the lower and higher groups for comparison.

\section{Research Question 2: Do college students with a history of familial dinnertime continue to dine with others at college?}

Students were likely to seek out a familial dining setting in college if they had a higher frequency of familial dining while growing up. However, a larger percentage of students in all groups reported eating in a familial setting only 0-3 times with other students while in college. This could be a result of the college lifestyle regarding class schedules and not meeting a lot of people to dine with.

Research Question 3: Does a higher frequency of familial dinnertime correlate to a higher quality diet in college?

College participants growing up eating in a familial dining setting $\geq 6$ days a week had a non-significant $(p \geq 0.05)$ increased intake of fruits, grains, and dairy compared to those $0-3$ times per week. There was a non-significant $(p \geq 0.05)$ decrease in daily convenience food consumption between the groups. These results support research that children with a history of familial dining 6-7 nights per week 
have a higher quality diet than those with a history of $0-3$ nights per week. While not all components of a healthful diet saw increased consumption, it is important to note that these students were more likely to eat fruits, grains, and dairy compared to their classmates.

\section{Research Question 4: Do college students with a higher frequency of familial dinners have other health benefits that can be assessed as part of a healthy lifestyle?}

Students were more likely to exercise, sleep and have a better BMI than those with 0-3 nights per week. The only significant change was noted in the GPA category. There was a non-significant $(p \geq 0.05)$ increase in exercising for at least 30 minutes a day outside of normal activities for 5-7 days per week (4\%), sleeping 7-9 hours a night $(20 \%)$, and BMI $(23 \%)$. A significant $(p=0.002)$ increase in GPA (54\%) was found between the two groups. These results support research that children with a history of familial dining 6-7 nights per week experience more health benefits than those with a history of 0-3 nights per week.

\section{Limitations}

The small sample size will limit the generalizability of the results, as does the selection of a convenience sample. Some previous studies have shown that middleupper class families are more health conscious and this could potentially affect the outcome of the study (Fritz, 2006).

One factor that this study did not control for was family social economical status. Dr. G.K. Fritz mentioned this along with other factors for the correlation between familial dinner and developmental outcomes (2006). While he mentions 
that the correlations happen more often than what could occur by chance, there are other influences that could play a role. For example, a family that is economically stable would have frequent family meals as well as better developmental outcome compared to a family that is not as economically stable.

\section{Conclusion}

These findings indicate that growing up eating in a familial dining setting $\geq 6$ days a week is associated with a better GPA in college. These findings may be used to support the importance of family mealtimes in outcomes for children.

\section{Recommendations for Future Studies}

This study indicates the need for further research that explores the influence

of familial dining on a variety of outcomes for children. Future studies could expand the efforts of this research by looking in depth at other variables on diet quality and lifestyle choices. All three analysis groups should be compared in further research. 


\section{References}

Addessi E, Galloway AT, Visalberghi E, Birch LL. (2005). Specific social influences on the acceptance of novel foods in 2-5 year old children. Appetite, 45: 264271.

Birch LL, Birch D, Marlin DW, Kramer L. (1982). Effects of instrumental consumption on children's food preference. Appetite, 3:125-134.

Birch LL, McPhee L, Steinberg L, Sullivan S. (1990). Conditioned flavor preferences in young children. Physiology \& Behavior, 47: 501-505.

Birch, L.L. and Davidson, K.K. (2001). Family environmental factors influencing the developing behavioral controls of food intake and childhood overweight. Pediatric Clinics of North America 48: 893-907. doi 10.1016/S00313955(05)70347-3.

Calculate your body mass index. National Heart, Lung, and Blood Institute. Retrieved from http://www.nhlbisupport.com/bmi

Fisher JO, Mitchell DC, Smickiklas-Wright H, Mannino ML, Birch LL. (2004). Meeting calcium recommendations during middle childhood reflects mother-daughter beverage choices and predicts bone mineral status. American Journal of Clinical Nutrition, 79: 698-706.

Fritz, G.K. (2006). The importance of the family dinner. The Brown University Child and Adolescent Behavior Letter, $\mathrm{p} 8$.

Gillman, M.W., Rifas-Shiman, S.L., Frazier, A.L., Rockett, H.R., Camargo, C.A., Jr., Field, A.E., et al. (2000). Family dinner and diet quality among older children 
and adolescents. Archives of Family Medicine 9: 235-240.

doi:10.1001/archfami.9.3.235.

Koivisto-Hursti, U.K. (1999). Factors influencing children's food choice. Ann. Med. 31 (Suppl 1): 26-32. PMID: 10342497

Neumark-Sztainer, D., Hanna, P.J., Story, M., Croll, J., \& Perry, C. (2003). Family meal patterns: associations with sociodemographic characteristics and improved dietary intake among adolescents. Journal of the American Dietetic Association, 103: 317-322. PMID: 12616252.

Nicklas, T.A., Demory-Luce, D., Yang, S.J., Baranowski, T., Zakeri, I., and Berenson, G. (2004). Children's food consumption patterns have changed over two decades (1973-1994): The Bogalusa heart study. Journal of the American Dietetic Association, 104: 1127-1140. doi:

10.1016/j.jada.2004.04.029. PMID: 15215772

Olivveria, S., Ellison, R., Moore, L., Gillman, M., Garrahie, E., \& Singer, M. (1992). Parent-child relationships in nutrient intake: The Framingham children's study. American Journal of Clinical Nutrition, 56, 593-598.

Rheingold, H. (1985). Development as the acquistion of familiarity. Annual Reviews in Psychology, 36:1-18.

Roblin, L. (2007). Childhood Obesity: Food, nutrient, and eating-habit trends and influences. Appl.Physiol. Nutr. Metab., 32: 635-645. doi: 10.1139?H07-046

Taveras, E.M., Rifas-Shiman, S.L., Berkey, C.S., Rockett, H.R., Field, A.E. Frazier, A.L., et al. (2005). Family dinner and adolescent overweight. Obesity Research. 13: 900-906. PMID: 15919844 
U.S. Department of Agriculture \& U.S. Department of Health and Human Services (2010). Dietary guidelines for Americans. Washington, D.C.: U.S. Government Printing Office.

Utter, J., Scragg, R., Schaaf, D., \& Mhurchu, C.N. (2008). Relationships between frequency of family meals, BMI and nutritional aspects of the home food environment among New Zealand adolescents. International Journal of Behavioral Nutrition and Physical Activity, 5:50. doi: 10.1186/1479-5868-5-50

Ventura, A., \& Birch, L. (2005). Does parenting affect children's eating and weight status? International Journal of Behavioral Nutrition and Physical Activity, $5: 15$

Veugelers, P.J., Fitzgerald, A.L., and Johnston, E. 2005. Dietary intake and risk factors for poor diet quality among children in Nova Scotia. Canadian Journal of Public Health, 96: 212- 216. PMID: 15913088

Wilson, N., Blakely, T., Foster, R.H., Hadorn, D., \& Vos, T. (2011). Prioritizing risk factors to identify preventive interventions for economic assessment. Bulletin of the World Health Organization, 90, 88-96. doi: 10.2471/BLT.11.091470 Woodruff, S.J., Hanning, R.M., McGoldrick, K., \& Brown, K.S. (2010). Healthy eating index-C is positively associated with family dinner frequency among students in grades 6-8 from Southern Ontario, Canada. European Journal of Clinical Nutrition, 64, 454-460. 


\section{Survey Questions based off of Research Objectives}

\begin{tabular}{|c|c|}
\hline Research Questions & Survey Questions \\
\hline $\begin{array}{l}\text { How frequently did students } \\
\text { share a family dinner while } \\
\text { growing up? }\end{array}$ & $\begin{array}{l}\text { 1. When you were growing up (elementary through } \\
\text { junior high), how often during the week did your } \\
\text { family sit down and eat an evening meal together? }\end{array}$ \\
\hline $\begin{array}{l}\text { Do college students with a history } \\
\text { of familial dinnertime continue to } \\
\text { dine with others at college? }\end{array}$ & $\begin{array}{l}\text { 1. How often do you eat an evening meal with at } \\
\text { least one other person a week in college? }\end{array}$ \\
\hline $\begin{array}{l}\text { Does a higher frequency of } \\
\text { familial dinnertime correlate to a } \\
\text { higher quality diet in college? }\end{array}$ & $\begin{array}{l}\text { 1. A serving of fruit is considered as a medium size } \\
\text { piece of fruit, } 1 / 2 \text { cup of canned fruit, or } 8 \text { oz serving } \\
\text { of } 100 \% \text { fruit juice. How many servings of fruit do } \\
\text { you typically consume? } \\
\text { 2. A serving of vegetables is considered as a } 1 / 2 \text { cup } \\
\text { of cooked or raw vegetables, or } 1 \text { cup of leafy } \\
\text { greens. How many servings of vegetables do you } \\
\text { typically consume? } \\
\text { 3. A serving of grains counts as } 1 \text { piece of bread, } 1 \\
\text { cup of cereal, or } 1 / 2 \text { cup of cooked pasta. How } \\
\text { many servings do you typically consume? } \\
\text { 4. How often were the servings you ate whole grain } \\
\text { such as brown rice, whole wheat, or oatmeal? } \\
\text { 5. A serving of dairy is considered to be } 1 \text { cup of milk } \\
\text { or yogurt, } 11 / 2 \text { ounces of natural cheese, or } 2 \\
\text { ounces of processed cheese. How many servings } \\
\text { of dairy do you typically consume? } \\
\text { 6. A serving of protein is considered to be } 1 \text { egg, } 1 \\
\text { ounce of nuts or seeds, } 2 \text { tablespoons peanut } \\
\text { butter, or } 1 \text { ounce of cooked meat. A small } \\
\text { hamburger or chicken breast is about } 3 \text { ounces. } \\
\text { How many servings of protein do you typically } \\
\text { consume? } \\
\text { 7. How often do you consume foods from convenient } \\
\text { sources such as fast food chains, gas stations, or } \\
\text { any form of pre-packaged dinners? }\end{array}$ \\
\hline $\begin{array}{l}\text { Do college students with a higher } \\
\text { frequency of familial dinners have } \\
\text { other health benefits that can be } \\
\text { assessed as part of a healthy } \\
\text { lifestyle? }\end{array}$ & $\begin{array}{l}\text { 1. How often do you exercise apart from normal } \\
\text { activities for at least } 30 \text { minutes? } \\
\text { 2. How many hours of sleep do you average a night? } \\
\text { 3. Height } \\
\text { 4. Weight } \\
\text { 5. GPA }\end{array}$ \\
\hline
\end{tabular}


Appendix B:

Survey Frequency Distribution with Significance Value

\begin{tabular}{|c|c|c|c|c|c|}
\hline \multicolumn{2}{|c|}{ Characteristics Measured } & \multirow{2}{*}{$\begin{array}{c}0-3 \text { Meal History } \\
\begin{array}{c}\text { Frequency } \\
(n=19)\end{array} \\
10\end{array}$} & \multirow{2}{*}{$\begin{array}{l}\begin{array}{l}\text { 4-5 Meal History } \\
\text { Frequency }(n=41)\end{array} \\
18\end{array}$} & \multirow{2}{*}{$\begin{array}{c}\text { 6-7 Meal History } \\
\begin{array}{c}\text { Frequency } \\
(n=40)\end{array} \\
10\end{array}$} & \multirow{3}{*}{$\begin{array}{r}\text { P Value } \\
0.002\end{array}$} \\
\hline \multirow{2}{*}{ GPA } & 2.1-3.0 & & & & \\
\hline & $3.1-4.0$ & 9 & 23 & 30 & \\
\hline \multirow{3}{*}{$\mathrm{BMI}$} & Underweight & 1 & 2 & 0 & \multirow{3}{*}{0.21} \\
\hline & Normal & 8 & 25 & 26 & \\
\hline & Overweight or Obese & 10 & 14 & 13 & \\
\hline \multirow{3}{*}{ Frequency in College } & $0-3$ times/week & 9 & 25 & 16 & \multirow{3}{*}{0.26} \\
\hline & 4-5 times/week & 5 & 6 & 10 & \\
\hline & 6-7 times/week & 5 & 10 & 14 & \\
\hline \multirow{5}{*}{ Fruit Intake } & 1-2 times/week & 4 & 9 & 8 & \multirow{5}{*}{0.39} \\
\hline & 3-4 times/week & 7 & 16 & 14 & \\
\hline & 5-6 times/week & 3 & 8 & 7 & \\
\hline & 1 time perday & 4 & 8 & 7 & \\
\hline & $2+$ times perday & 1 & 0 & 4 & \\
\hline \multirow{5}{*}{ Vegetable Intake } & 1-2 times/week & 3 & 9 & 8 & \multirow{5}{*}{0.29} \\
\hline & 3-4 times/week & 9 & 19 & 12 & \\
\hline & 5-6 times/week & 2 & 8 & 3 & \\
\hline & 1 time perday & 0 & 5 & 7 & \\
\hline & $2+$ times per day & 5 & 0 & 10 & \\
\hline \multirow{6}{*}{ Grains } & 1-2 times/week & 0 & 2 & 3 & \multirow{6}{*}{0.49} \\
\hline & 3-4 times/week & 4 & 13 & 7 & \\
\hline & 5-6 times/week & 4 & 8 & 4 & \\
\hline & 1-2 times per day & 5 & 9 & 12 & \\
\hline & $3-4 t$ times per day & 4 & 5 & 9 & \\
\hline & $5+$ times perday & 2 & 4 & 5 & \\
\hline \multirow{5}{*}{ Whole Grains } & Almost never or never & 4 & 8 & 5 & \multirow{5}{*}{0.31} \\
\hline & About $1 / 4$ of the time & 4 & 15 & 15 & \\
\hline & About $1 / 2$ of the time & 5 & 11 & 11 & \\
\hline & About $3 / 4$ of the time & 2 & 3 & 5 & \\
\hline & Almost always or always & 4 & 4 & 4 & \\
\hline & 1-2 times/week & 1 & 4 & 3 & \multirow{5}{*}{0.35} \\
\hline & 3-4 times/week & 7 & 10 & 8 & \\
\hline Dairy & 5-6 times/week & 0 & 8 & 6 & \\
\hline & 1 time perday & 5 & 7 & 9 & \\
\hline & $2+$ times per day & 6 & 12 & 14 & \\
\hline & $1-2$ times/week & 0 & 3 & 3 & \\
\hline & 3-4 times/week & 4 & 10 & 10 & \\
\hline Protein & 5-6 times/week & 4 & 10 & 4 & 0.34 \\
\hline & 1 time per day & 2 & 7 & 8 & \\
\hline & $2+$ times perday & 9 & 11 & 15 & \\
\hline & 1-2 times/week & 9 & 22 & 21 & \\
\hline & 3-4 times/week & 4 & 13 & 12 & \\
\hline Convenience Food & 5-6 times/week & 2 & 4 & 4 & 0.12 \\
\hline & 1 time perday & 1 & 1 & 3 & \\
\hline & $2+$ times perday & 3 & 1 & 0 & \\
\hline & $1-2$ times/week & 6 & 16 & 17 & \\
\hline & 3-4 times/week & 7 & 15 & 12 & \\
\hline Exercise & 5-6 times/week & 3 & 6 & 8 & 0.14 \\
\hline & 1 time per day & 1 & 4 & 2 & \\
\hline & $2+$ times per day & 2 & 0 & 1 & \\
\hline & $0-3$ hours & 0 & 2 & 0 & \\
\hline Sleep & 4-6 hours & 9 & 13 & 11 & 008 \\
\hline Sleep & $7-9$ hours & 10 & 26 & 29 & \\
\hline & $10+$ hours & 0 & 0 & 0 & \\
\hline
\end{tabular}




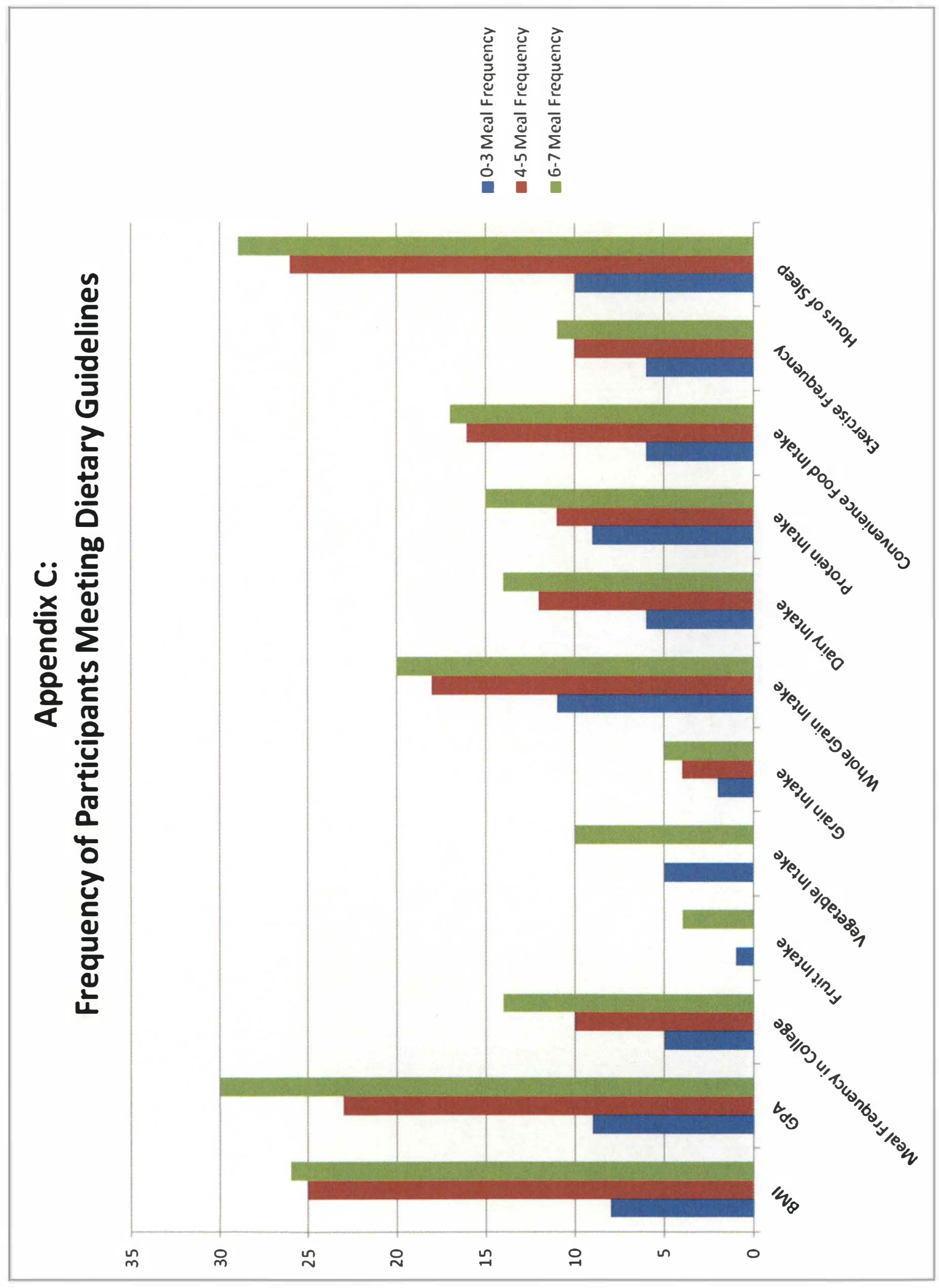

